\title{
The microbiological effects of hospital wastes on the environment
}

\author{
Oyeleke, S. B.* and Istifanus, N. \\ Department of Microbiology, Federal University of Technology, Minna. \\ Accepted 21 July, 2009
}

\begin{abstract}
The effect of 24 hospital wastes samples taking from different hospitals waste dumpsites on its surrounding soil was examined. The counts of microorganisms in hospital dumpsite soil include the following; aerobic heterotrophic counts varies from $4.2 \times 10^{5}$ to $1.6 \times 10^{10}$, the anaerobic heterotrophic counts varies from $1.0 \times 10^{5}$ to $1.6 \times 10^{9}$ while fungi counts 0 to $6.9 \times 10^{6}$ while the counts in soil adjacent to dumpsites include the following; aerobic heterotrophic counts varies from $1.0 \times 10^{5}$ to $4.0 \times 10^{9}$, the anaerobic heterotrophic counts varies from $1.0 \times 10^{5}$ to $5.0 \times 10^{8}$ while fungi counts is between 0 to $1.0 \times$ $10^{6}$. Bacteria isolated at the soil dumpsite and soil adjacent to dumpsites respectively include Bacillus sp $(42.86 ; 45 \%)$, Micrococcus roseus $(14.29 ; 10 \%)$,Staphylococcus epidermidis (9.52, 10\%), Corynebacterium equi (1.59; $5 \%)$, Bacillus subtilis (4.76; $5 \%)$, B. licheniformis $(9.52 ; 10 \%)$, Actinomyces israeli (3.17; 5\%) while fungi isolated include Rhizopus nigricans (27.59; 18.52\%), Aspergillus flavus (13.79; 3.70\%), Penicillium rubrum (6.86; 3.70\%), Trichothecium roseum (0; 3.70\%), Penicillium viricadum (6.90; 0\%) Aspergillus niger (34.48; 44.44\%), Aspergillus nidulans (0; 11.11\%), Aspergillus visicolor (3.45; 3.45\%), Aspergillus parasiticus (0; 7.41\%), and Microsporum canis (6.9; $0 \%)$. The dumpsites soil recorded higher $\mathrm{pH}$ value than the adjacent soil. The investigation revealed that the hospital waste dumpsites may have adverse effects on its immediate environment.
\end{abstract}

Key words: Hospital wastes, aerobic counts, anaerobic heterotrophic counts, soil dump site and soil adjacent.

\section{INTRODUCTION}

"Hospital wastes" (or solid waste) refers to all waste, biological or non biological, that is discarded and not intended for further use (USEPA, 1989) and these include: pathological, infectious, hazardous chemicals, radioactive wastes, stock cultures, blood and blood products, animal carcasses, pharmaceutical wastes, pressurized containers, batteries, plastics, low level radioactive wastes, disposable needles, syringes, scalpels and other sharp items. These are in addition to food service, clinical bandages, gauze, cotton, cotton and other miscellaneous wastes. Other types of waste include toxic chemicals, cytotoxic drugs, flammable and radioactive wastes that can often be considered infectious (Caltivelli, 1990). As regards live pathogens found in hospital wastes, the most predominant (80-90\%) is the genus Bacillus with Staphylococci and Streptococci varying between 5 and 10\%, where as the most common pathogens is Staphylo-

\footnotetext{
${ }^{\star}$ Corresponding author. E-mail: droyeleke@yahoo.com.
}

coccus aureus (from 2-10 colonies per gram of waste). Escherichia coli, Pseudomonas aeruginosa and Candida albicans are also common along with varying numbers of other common nosocomial pathogens such as Klebsiella Proteus and Enterobacter species. The survival rate of viruses has revealed that most material that are present in hospital wastes are able to carry viruses keeping them alive for several days (5 - 8 days). However the viral titre tends to decrease rapidly as time passes; for example the Hepatitis $B$ virus has been detected but its potential to provoke infection has not been established. The pathogens present in the wastes can leach out and contaminate ground water and surface water. Harmful Chemicals present in biomedical waste such as heavy metals can also cause water pollution; poor land filling technology may cause water pollution in the form of leachates. Excess nutrient leachate such as nitrates and phosphates from landfills can cause a phenomenon called eutrophication (when surface of the water body develops algal blooms). Water pollution can alter parameters such as $\mathrm{pH}$, Biochemical Oxygen Demand (BOD) 
and Chemical Oxygen Demand (COD). There are instances where dioxins are reported from water bodies near incinerating plants. Dioxins enter the water body from the air (Annon, 2004).

The aim and objectives of the study are to ascertain the effect of hospital solid wastes on the surrounding soil at the dump sites and to isolate, identify and characterize the microbial population in the wastes.

\section{METHODS}

\section{Collection and analysis of hospital soil samples}

The samples for microbiological analysis were collected in sterile universal containers while samples for physico-chemical analysis were collected in clean polythene bags. The soil samples were collected from hospital dumpsites and from soil adjacent to the dumpsites site. Soil from 24 hospital dumpsites, were taken in Minna and Suleja Niger state, Nigeria, from the month of January to April, 2006.

Isolation, characterization, enumeration and identification of microorganism from hospital wastes dumpsite soil and soil adjacent to the dumpsite

Bacteria were isolated and characterized using cultural identification, morphological identification using gram staininig reaction and other biochemical tests which include; catalase, methyl red, voges proskauer (MR-VP), nitrate reduction test, starch hydrolysis, gelatin liquefaction test, coagulase, indole, motility, oxidase, urease, triple sugar iron agar (TSI) and sugar fermentation as described by Ogbulie et al. (1998) and Cheesbrough (2003) while fungi was isolated using the growth rate, colonial morphological features and microscopic morphological features. The colour of aerial hyphae and substrate hyphae was observed and staining procedure as described by Ellen and Sydney (1990) Cheesbrough (2003).

\section{Physico-chemical analysis}

The physico-chemical analysis carried out include the $\mathrm{pH}$, moisture content, temperature, chloride lon, dissolved oxygen, organic matter and total suspended solids as described by (Ademoroti, 1996).

\section{RESULTS AND DISCUSSION}

The aerobic heterotrophic plate count of hospital wastes dumpsite soil and that of soil adjacent to the dumpsite shows an insignificant difference $(P>0.05)$ (Table 1). The reasons for the insignificant difference in the aerobic heterotrophic plate count could be as stated by Ayliffe, (1992) that healthcare wastes do not seem to provide favourable media for the survival of pathogens, because they frequently contain antiseptics. Other reason for the insignificant difference could be due to predation, extreme $\mathrm{pH}$, high temperature and moisture content as stated by Stevick et al. (2004).

There is a significant difference $(P<0.05)$ in the ana- erobic heterotrophic plate counts of the hospital wastes dumpsites soil to that of the soil adjacent to the dumpsites. (Table 1) The hospital wastes could have contributed immensely in the increase of these bacteria. Jager et al. (1989) reported the isolation of these bacteria from the wastes of different hospitals. Irene (1996) stated that during the wet season water can drain carrying these organisms to local surface water, ground water or the sea.

The high fungi count of the hospital wastes dumpsites soil (Table 1) might be due to the fact that hospital wastes is very rich in organic material and fungi, as stated by Rheinheimer (1991) are heterotrophic organism that depends on the presence of organic material. The bacteria isolated include, Bacillus sp., Micrococcus luteus, Staphylococcus epidermidis, Neisseria sicca and Micrococcus roseus. Others are Corynebacterium equi, Bacillus subtilis, B. licheniformis and Actinomyces istraelii. Bacillus was found to be the predominant species isolated (Table 2). This finding was in agreement with that of other investigators, Giroletti and Lodola (1993) who reported that Bacillus was the predominant genus found in hospital wastes. These organisms are saprophytes and represent a large number of different species. They are found in soil, water, dust and air as stated by Duguid et al. (1987).

The bacteria: $M$. leteus, $S$. epidermidis, $N$. sicca, $M$. roseus, $B$. subtilis and $B$. licheniformis that were isolated from the dumpsite soil were reported by Duguid et al. (1987) to be harmless commensals but occasionally act as opportunistic pathogens. Garoletti and Lodola (1993) isolated staphylococci varying between 5 and $10 \%$ of the isolates from hospital wastes which agrees with this findings, of which S. epidermidis accounted for $9.52 \%$ of the total isolates.

A. istraelii has about $3.17 \%$ appearance in the dumpsite soil and $5 \%$ appearance in the soil adjacent to the dumpsites. This organism is a commensal in the buccal cavity but it causes actinomycosis, a chronic suppurative disease as stated by Ernest et al. (1984), C. equi has the least percentage appearance of $1.59 \%$ in the dumpsite soil and $5 \%$ in the soil adjacent to the dumpsite. This organism as stated by Ellen and Sydney (1990) is associated with human infection. The fungi species that were identified were Rhizopus nigricans, Aspergillus flavus Penicillium rubrum, Trichothecium roseum, Penicillium viricadum and Aspergillus niger. Others are: Aspergillus nidulans, Aspergillus. parasiticus and Microsporum canis, Aspergillus niger was frequently isolated with percentage appearance of $34.5 \%$ for dumpsites soil (Table 3). According to Alexopoulos and Mims (1979), Aspergillus are capable of utilizing an enormous variety of substrates for food because of the large numbers of enzymes they produce $A$. niger and $A$. flavus are animal and human pathogens that cause a group of diseases collectively known as aspergillosis. The non pathogenic mold $R$. nigricans was the next with 
Table 1. Microbial counts of soil of hospital dumpsites and counts of its adjacent soil.

\begin{tabular}{|c|c|c|c|c|c|c|}
\hline \multirow[t]{2}{*}{$\begin{array}{l}\text { Sample } \\
\text { code }\end{array}$} & \multicolumn{3}{|c|}{$\begin{array}{l}\text { Counts of bacteria in different hospital } \\
\text { wastes }(\mathrm{cfu} / \mathrm{g})\end{array}$} & \multicolumn{3}{|c|}{$\begin{array}{l}\text { Counts of bacteria in soil adjacent to the } \\
\text { dumpsites (cfu) } / \mathrm{g}\end{array}$} \\
\hline & $\begin{array}{c}\text { Aerobic } \\
\text { heterotrophic } \\
\text { counts }\end{array}$ & $\begin{array}{c}\text { Anaerobic } \\
\text { heterotrophic } \\
\text { counts }\end{array}$ & $\begin{array}{l}\text { Fungal } \\
\text { counts }\end{array}$ & $\begin{array}{c}\text { Aerobic } \\
\text { heterotrophic } \\
\text { counts }\end{array}$ & $\begin{array}{c}\text { Anaerobic } \\
\text { heterotrophic } \\
\text { counts }\end{array}$ & $\begin{array}{l}\text { Fungal } \\
\text { counts }\end{array}$ \\
\hline $\mathrm{AH}_{\mathrm{I}}$ & $2.9 \times 10^{9}$ & $1.7 \times 10^{8}$ & $7.0 \times 10^{5}$ & $2.9 \times 10^{9}$ & $1.7 \times 10^{8}$ & $7.0 \times 10^{5}$ \\
\hline $\mathrm{BH}_{1}$ & $2.5 \times 10^{9}$ & $1.0 \times 10^{8}$ & $4.2 \times 10^{5}$ & $2.5 \times 10^{9}$ & $1.0 \times 10^{8}$ & $4.2 \times 10^{5}$ \\
\hline $\mathrm{CH}_{1}$ & $3.0 \times 10^{6}$ & $2.0 \times 10^{8}$ & $8.0 \times 10^{5}$ & $3.0 \times 10^{6}$ & $2.0 \times 10^{8}$ & $8.0 \times 10^{5}$ \\
\hline $\mathrm{DH}_{1}$ & $3.0 \times 10^{8}$ & $1.0 \times 10^{8}$ & $6.9 \times 10^{6}$ & $3.0 \times 10^{8}$ & $1.0 \times 10^{8}$ & $6.9 \times 10^{6}$ \\
\hline $\mathrm{EH}_{1}$ & $1.6 \times 10^{10}$ & $1.6 \times 10^{9}$ & $1.0 \times 10^{6}$ & $1.6 \times 10^{10}$ & $1.6 \times 10^{9}$ & $1.0 \times 10^{6}$ \\
\hline $\mathrm{FH}_{1}$ & $1.6 \times 10^{9}$ & $1.5 \times 10^{9}$ & $3.0 \times 10^{5}$ & $1.6 \times 10^{9}$ & $1.5 \times 10^{9}$ & $3.0 \times 10^{5}$ \\
\hline $\mathrm{GH}_{1}$ & $2.3 \times 10^{6}$ & $1.3 \times 10^{8}$ & $3.0 \times 10^{5}$ & $2.3 \times 10^{6}$ & $1.3 \times 10^{8}$ & $3.0 \times 10^{5}$ \\
\hline $\mathrm{HH}_{1}$ & $6.0 \times 10^{6}$ & $1.0 \times 10^{5}$ & 0 & $6.0 \times 10^{6}$ & $1.0 \times 10^{5}$ & 0 \\
\hline $\mathrm{JH}_{1}$ & $1.6 \times 10^{8}$ & $1.3 \times 10^{6}$ & $1.0 \times 10^{6}$ & $1.6 \times 10^{8}$ & $1.3 \times 10^{6}$ & $1.0 \times 10^{6}$ \\
\hline $\mathrm{MH}_{1}$ & $1.8 \times 10^{6}$ & $1.0 \times 10^{6}$ & $4.0 \times 10^{5}$ & $1.8 \times 10^{6}$ & $1.0 \times 10^{6}$ & $4.0 \times 10^{5}$ \\
\hline $\mathrm{NH}_{1}$ & $2.5 \times 10^{6}$ & $2.0 \times 10^{5}$ & $2.0 \times 10^{5}$ & $2.5 \times 10^{6}$ & $2.0 \times 10^{5}$ & $2.0 \times 10^{5}$ \\
\hline $\mathrm{OH}_{1}$ & $2.2 \times 10^{8}$ & $6.2 \times 10^{5}$ & $6.2 \times 10^{5}$ & $2.2 \times 10^{8}$ & $6.2 \times 10^{5}$ & $6.2 \times 10^{5}$ \\
\hline $\mathrm{PH}_{1}$ & $9.6 \times 10^{8}$ & $6.0 \times 10^{5}$ & $8.2 \times 10^{5}$ & $9.6 \times 10^{8}$ & $6.0 \times 10^{5}$ & $8.2 \times 10^{5}$ \\
\hline $\mathrm{QH}_{1}$ & $7.0 \times 10^{5}$ & $2.0 \times 10^{5}$ & $2.0 \times 10^{5}$ & $7.0 \times 10^{5}$ & $2.0 \times 10^{5}$ & $2.0 \times 10^{5}$ \\
\hline $\mathrm{RH}_{1}$ & $7.6 \times 10^{5}$ & $2.0 \times 10^{5}$ & $1.0 \times 10^{5}$ & $7.6 \times 10^{5}$ & $2.0 \times 10^{5}$ & $1.0 \times 10^{5}$ \\
\hline $\mathrm{SH}_{1}$ & $6.2 \times 10^{8}$ & $1.2 \times 10^{6}$ & $1.0 \times 10^{6}$ & $6.2 \times 10^{8}$ & $1.2 \times 10^{6}$ & $1.0 \times 10^{6}$ \\
\hline $\mathrm{TH}_{1}$ & $4.2 \times 10^{5}$ & $2.0 \times 10^{5}$ & $2.0 \times 10^{5}$ & $4.2 \times 10^{5}$ & $2.0 \times 10^{5}$ & $2.0 \times 10^{5}$ \\
\hline $\mathrm{UH}_{1}$ & $1.2 \times 10^{7}$ & $3.0 \times 10^{5}$ & $2.2 \times 10^{5}$ & $1.2 \times 10^{7}$ & $3.0 \times 10^{5}$ & $2.2 \times 10^{5}$ \\
\hline $\mathrm{VH}_{1}$ & $5.3 \times 10^{5}$ & $4.0 \times 10^{5}$ & $6.6 \times 10^{5}$ & $5.3 \times 10^{5}$ & $4.0 \times 10^{5}$ & $6.6 \times 10^{5}$ \\
\hline $\mathrm{WH}_{1}$ & $1.8 \times 10^{6}$ & $8.0 \times 10^{5}$ & $7.2 \times 10^{5}$ & $1.8 \times 10^{6}$ & $8.0 \times 10^{5}$ & $7.2 \times 10^{5}$ \\
\hline $\mathrm{XH}_{1}$ & $6.6 \times 10^{5}$ & $1.0 \times 10^{5}$ & $8.2 \times 10^{5}$ & $6.6 \times 10^{5}$ & $1.0 \times 10^{5}$ & $8.2 \times 10^{5}$ \\
\hline $\mathrm{YH}_{1}$ & $2.4 \times 10^{5}$ & $4.0 \times 10^{5}$ & $6.0 \times 10^{5}$ & $2.4 \times 10^{5}$ & $4.0 \times 10^{5}$ & $6.0 \times 10^{5}$ \\
\hline $\mathrm{ZH}_{1}$ & $1.8 \times 10^{8}$ & $1.3 \times 10^{6}$ & $9.0 \times 10^{5}$ & $1.8 \times 10^{8}$ & $1.3 \times 10^{6}$ & $9.0 \times 10^{5}$ \\
\hline $\mathrm{I}_{1} \mathrm{H}_{1}$ & $1.0 \times 10^{8}$ & $2.2 \times 10^{5}$ & $2.0 \times 10^{5}$ & $1.0 \times 10^{8}$ & $2.2 \times 10^{5}$ & $2.0 \times 10^{5}$ \\
\hline$x$ & $6.4331 \times 10^{4}$ & $1.2334 .8 \times 10^{4}$ & $5.575 \times 10^{1}$ & & & \\
\hline$\delta^{2} n-1$ & $5.77187 \times 10^{10}$ & $1.0586 \times 10^{9}$ & $9.674 \times 10^{3}$ & & & \\
\hline$\Delta \mathrm{n}-1$ & $2.40247 \times 10^{5}$ & $3.2536 .5 \times 10^{4}$ & $9.8358 \times 10^{1}$ & & & \\
\hline & $\mathrm{H}_{\mathrm{o}}$ - accepted & Ho - Rejected & $\begin{array}{c}\mathrm{H}_{\circ}= \\
\text { Rejected }\end{array}$ & & & \\
\hline
\end{tabular}

Table 2. The frequency of isolation of bacteria from soil of hospital dumpsites and soil adjacent to the dumpsites.

\begin{tabular}{|l|c|c|c|c|}
\hline \multirow{2}{*}{ Isolate } & \multicolumn{2}{|c|}{ Hospital dumpsites soil } & \multicolumn{2}{c|}{ Soil adjacent } \\
\cline { 2 - 5 } & $\begin{array}{c}\text { Total number of } \\
\text { isolates }\end{array}$ & $\begin{array}{c}\text { Percentage (\%) } \\
\text { appearance }\end{array}$ & $\begin{array}{c}\text { Total number } \\
\text { of isolates }\end{array}$ & $\begin{array}{c}\text { Percentage (\%) } \\
\text { appearance }\end{array}$ \\
\hline Bacillus sp. & 27 & 42.86 & 27 & 45 \\
M. luteus & 9 & 14.29 & 6 & 10 \\
S. epidermidis & 6 & 9.52 & 6 & 10 \\
N. sicca & 3 & 4.76 & 3 & 5 \\
M. roseus & 6 & 9.52 & 3 & 5 \\
C. equi & 1 & 1.59 & 3 & 5 \\
B. subtilis & 3 & 4.76 & 3 & 5 \\
B. licheniformis & 6 & 9.52 & 6 & 10 \\
A. istraelii & 2 & 3.17 & 3 & 5 \\
\hline
\end{tabular}


Table 3. Frequency of isolation of fungi isolates from soil of hospital dumpsite and soil adjacent to the dumpsites.

\begin{tabular}{|l|c|c|c|c|}
\hline \multirow{2}{*}{$\begin{array}{l}\text { Isolated } \\
\text { fungi }\end{array}$} & \multicolumn{2}{|c|}{ Hospital dumpsites soil } & \multicolumn{2}{c|}{ Soil adjacent to dumpsites } \\
\cline { 2 - 5 } & $\begin{array}{c}\text { Number of } \\
\text { appearance }\end{array}$ & $\begin{array}{c}\text { Percentage \% } \\
\text { appearance }\end{array}$ & $\begin{array}{c}\text { Number of } \\
\text { appearance }\end{array}$ & $\begin{array}{c}\text { Percentage } \% \\
\text { appearance }\end{array}$ \\
\hline R. nigricans & 8 & 27.59 & 5 & 18.52 \\
A. flavus & 4 & 13.79 & 1 & 3.70 \\
P. rubrum & 2 & 6.86 & 1 & 3.70 \\
$\begin{array}{l}\text { T. roseum } \\
\text { P. viricadum }\end{array}$ & 2 & 6.90 & 1 & 3.70 \\
$\begin{array}{l}\text { A. niger } \\
\text { A. nidulans }\end{array}$ & 10 & 34.48 & 12 & 44.44 \\
$\begin{array}{l}\text { A. visicolor } \\
\text { A. parasiticus }\end{array}$ & 1 & 3.45 & 3 & 11.11 \\
M. canis & 2 & 6.9 & 1 & 3.7 \\
Unidentified & & & 2 & 7.41 \\
\hline
\end{tabular}

Table 4. The moisture content and $\mathrm{pH}$ of soil of hospital dumpsites and that of soil adjacent to the dumpsites.

\begin{tabular}{|c|c|c|c|c|}
\hline \multirow{2}{*}{$\begin{array}{c}\text { Sample } \\
\text { code }\end{array}$} & \multicolumn{2}{|c|}{ Soil of hospital dumpsites } & \multicolumn{2}{|c|}{ Soil adjacent to dumpsites } \\
\cline { 2 - 5 } & Moisture content (\%) & $\mathbf{p H}$ & Moisture content (\%) & $\mathbf{p H}$ \\
\hline $\mathrm{AH}_{1}$ & 7.6 & 6.8 & $\mathrm{AH}_{1}$ & 7.6 \\
$\mathrm{BH}_{1}$ & 3.6 & 7.9 & $\mathrm{BH}_{1}$ & 3.6 \\
$\mathrm{CH}_{1}$ & 4.6 & 8.1 & $\mathrm{CH}_{1}$ & 4.6 \\
$\mathrm{DH}_{1}$ & 4.2 & 7.2 & $\mathrm{DH}_{1}$ & 4.2 \\
$\mathrm{EH}_{1}$ & 6.9 & 7.9 & $\mathrm{EH}_{1}$ & 6.9 \\
$\mathrm{FH}_{1}$ & 6.4 & 8.9 & $\mathrm{FH}_{1}$ & 6.4 \\
$\mathrm{GH}_{1}$ & 6.8 & 7.6 & $\mathrm{GH}_{1}$ & 6.8 \\
$\mathrm{HH}_{1}$ & 4.1 & 9.2 & $\mathrm{HH}_{1}$ & 4.1 \\
$\mathrm{IH}_{1}$ & 4.2 & 7.2 & $\mathrm{IH}_{1}$ & 4.2 \\
$\mathrm{JH}_{1}$ & 4.4 & 9.2 & $\mathrm{JH}_{1}$ & 4.4 \\
$\mathrm{MH}_{1}$ & 5.8 & 9.0 & $\mathrm{MH}_{1}$ & 5.8 \\
$\mathrm{NH}_{1}$ & 4.4 & 8.8 & $\mathrm{NH}_{1}$ & 4.4 \\
$\mathrm{OH}_{1}$ & 4.6 & 7.6 & $\mathrm{OH}_{1}$ & 4.6 \\
$\mathrm{PH}_{1}$ & 4.8 & 7.7 & $\mathrm{PH}_{1}$ & 4.8 \\
$\mathrm{QH}_{1}$ & 3.8 & 7.8 & $\mathrm{QH}_{1}$ & 3.8 \\
$\mathrm{RH}_{1}$ & 3.8 & 8.5 & $\mathrm{RH}_{1}$ & 3.8 \\
$\mathrm{SH}_{1}$ & 6.0 & 7.6 & $\mathrm{SH}_{1}$ & 6.0 \\
$\mathrm{TH}_{1}$ & 3.7 & 8.2 & $\mathrm{TH}_{1}$ & 3.7 \\
$\mathrm{UH}_{1}$ & 4.2 & 8.8 & $\mathrm{UH}_{1}$ & 4.2 \\
$\mathrm{VH}_{1}$ & 4.6 & 8.0 & $\mathrm{VH}_{1}$ & 4.6 \\
$\mathrm{WH}_{1}$ & 4.4 & 7.8 & $\mathrm{WH}_{1}$ & 4.4 \\
$\mathrm{XH}_{1}$ & 4.0 & 8.9 & $\mathrm{XH}_{1}$ & 4.0 \\
$\mathrm{YH}_{1}$ & 3.8 & 9.1 & $\mathrm{YH}_{1}$ & 3.8 \\
\hline
\end{tabular}

percentage appearance of $27.50 \%$ in the dumpsites soil.

$P$. viricadum and $P$. rubrum are not known to cause any disease except in severely immuno compromised patients (Ernest et al., 1984). The $T$. roseum that was isolated from the adjacent soil as stated by Bernward and
Garbriele (1980) was a non pathogenic fungi which grows on wood, paper, fruits and vegetable. $M$. canis constitute the remaining percentage. This organism causes infection in domestic animals (cat and dogs) and can transmit this infection to humans as stated by Ernest et 
al. (1984) as these animals were always sighted around these dumpsites.

The high $\mathrm{pH}$ value of the dumpsite soil (Table 4) may be as a result of the ash been generated from open burning of the waste. These ashes can find their way to water bodies and soil resulting in water and land pollution as outline by Annon (2004).

\section{REFERENCES}

Ademoroti CMA (1996). Standard Methods for Water and Effluent Analysis. Foludex Press Ltd. Ibadan. Nigeria. pp. 27-30, 44-71, 103112.

Alexopoulos CY, Mims CW (1979). Introductory Mycology. $3^{\text {rd }}$ edition. John Wiley and Sons New York. p. 291.

Annon (2004). Bio-medical waste management in Bangalore. Ministry of Environment and Forest notification. New Delhi. p. 1-5

Ayliffe $G$ (1992). Control of hospital infection: A practical handbook. $3^{\text {rd }}$ edition. London, Chapman \& Hall, Medical, p. 6.

Caltivelli EG (1990). In medical waste Treatment Ispracourses; Waste Treatment manage. 1973: 1-12

Cheesbrough M (2003). Water quality analysis. District Laboratory practice in Tropical countries (2) Cambridge University Press. United Kingdom. pp. 146-157.
Duguid JP, Marmion BP, Swain RHA (1987). Medical Microbiology. Churchill Livingstone Publishers. pp. 120-200

Ernest J, Joseph LM, Edward AD (1984). Review of Medical Microbiology $16^{\text {th }}$ edition. Lange Medical Publications Los Altos, Calfornia. pp. 56-112

Ellen JB, Sydney MF (1990). Diagnostic Microbiology. $8^{\text {th }}$ edition. C.V. Mosby company USA. p. 468.

Giroletti E, Lodola L (1993). ISPRA COURSES: Waste Treatment and Management. Med. Waste Treatment, pp. 1-8

Irene MC (1996). Characteristics and Treatment of Leachates from Domestic Landfills. Environ. Int. 22(4): 433-442

Jager E, Xander L, Ruden H (1989). Hospital wastes. Communication: Microbiological Investigations of Hospital Waste From various wards of a big and of smaller Hospital in comparison to household Refuse. Hygiene, 188: 345-364.

Ogbulie JN, Uwazuoke JC, Ogieho SI (1998). Introductory Microbiology Practical. Springfield Publishers Nigeria. pp. 70-120.

Odokuma LO, Okpokwasili (1993). Seasonal influence on inorganic Anion Monitoring of the new Calabar River, Nigeria, Environ. Manage. 17(4): 491-496

Stevik TK, Karia A, Ausland G, Hanssen JF (2004) Retention and Removal of Pathogenic Bacteria in Wastewater Percolating Through Porous Media: a review: Water Res. pp. 1355-1367.

USEPA (1989B). Standards method for the treating and management of medical waster: Interim final rule and request for comments. pp. 7111. 